\title{
Evaluation of Food Rationing and Subsidy Program
}

\author{
Sally Ezzat*
}

\begin{abstract}
Egypt's food rationing and subsidy system has been a mainstay of the government's longterm policy of promoting social equity and political stability. There is an increasing pressure to reform if not eliminating the subsidy program. Few studies were carried-out to evaluate the current subsidy system. The aim of this study is to assess the consumption of subsidized and unsubsidized bread, identify the factors affecting dispensing rationed foods and to determine consumer's opinion towards the subsidy program. The subjects of this study were 204 employees from Alexandria University hospitals. Data were collected by direct interview using a predesigned questionnaire. Data were collected on the socioeconomic characteristics of the family, purchase of subsidized balady and unsubsidized shami and fino bread. The fate of the subsidized bread and consumers' suggestions to improve its quality were assessed. The rate of dispensing foods through ration cards was determined. Consumers' opinion of the nutritional values of the subsidized foods and the preferred mode of subsidy were recorded. The results show that subsidized balady bread was consumed by all social strata, the percapita share of low socioeconomic groups was more than 3 loafs daily. Shami and Fino bread was consumed mostly by high income bracket. The results show that $14.2 \%$ of the balady bread was wasted and $10.8 \%$ was refrigerated. The majority $(46.7 \%)$ recommended no change in the current bread subsidy system and $28.9 \%$ recommended improved baking. The quantity of foods dispensed by ration card varied with the type of food. The whole quantity of allocated sugar was dispensed by $78.0 \%$ of the sample compared with tea which was least collected $(49.5 \%)$. Poor quality was the main reason for not dispensing the whole quantity, however, it was reported by some consumers that the rationed quantity of sugar and oil exceeded their needs. The results show that $48.0 \%$ of the sample believed that food subsidy improves nutrition while $28.9 \%$ reported that it has no effect. The present card system of delivering subsidized food was preferred $(52.0 \%)$ fearing that cash subsidy will not be enough $(54.7 \%)$ or will be associated with a sharp increase in food price.
\end{abstract}

Key words: Food; Bread; Subsidy; Ration Cards; Socioeconomic Factors.

\section{INTRODUCTION}

Egypt's food rationing and subsidy system

has been a mainstay of the government's

long-term policy of promoting social equity

and political stability. It has been a major component of the social safety net for the

poor, guaranteeing the availability of affordable stables and minimizing the adverse effects of recent economic reform and structural adjustment. (1) Food rationing

\footnotetext{
*Fellow of Nutrition Alexandria University Students' hospital
} 
began as a temporary measure in Egypt in 1941, with a goal of helping Egyptians cope with food scarcity and inflation resulting from World War II. The initial system was not targeted to the poor, but was instead set up to provide necessities such as sugar, kerosene, edible oil, and tea. (2) Wheat, in turn, was not rationed, but was subsidized in the years following the war.(3) Following "July Revolution" in 1952, agrarian reforms marked the beginning of extensive government involvement in the production, marketing and distribution of most agricultural products, which lasted until the start of liberalization of state agriculture in 1987.(4)

In the mid-1960s, ration cards were used for the distribution of a small number of goods and did not always involve price subsidies and were designed as a quantityrationing system. In general, spending on food subsidies remained a modest percentage of the government's budget, and the role of food subsidy policies was primarily to ensure the support of essential food items. ${ }^{(5)}$ The costs of the expanding system continued to grow and the subsidy system was becoming increasingly unsustainable. By 1981, almost all the population had ration cards, of which 97 percent were the more highly subsidized green ration cards. ${ }^{(6)}$

In 1982, a process of reforming the food subsidy system was initiated. This was achieved by reducing the number of subsidized foods, reduction in the number of people on the ration card system and a slow reduction in subsidies by reducing the weight of subsidized food, or replacing it by a more expensive version. Bread price was increased by this strategy to 5 piasters in 1988, without popular protest. In 1996, the government introduced unsubsidized version of fino bread and 72 percent extraction flour used for the preparation of shami bread. The result of these frequent policy steps has led to a reduction of subsidized foods to sugar, oil, rice and tea 
which are dispensed through the ration card and subsidized balady bread which is sold freely.

Consumer price subsidy have been studied on a variety of fronts, particularly the economic and social impact of such programs, its negative impact on the national economy and the leakage of these subsidies to the rich. Surprisingly few studies have focused on their nutritional impact. The nutritional impact of food price subsidy depends on the nutritive value of the subsidized food, the degree of subsidy and the ability of the beneficiaries to purchase the subsided foods. Kochar (2005) found that India's subsidy program has only a limited effect on calorie intake (7). This was attributed to the low take-up rates and low purchases of subsidized goods. The reasons for the low take-up rates and use were not clear. ${ }^{(8)}$ On the other hand, targeted fruit and vegetable subsidy among low-income women in special supplemental nutrition program proved to be very effective in increasing fruit and vegetables consumption. ${ }^{(9)}$ Tortilla subsidy in Mexico was followed by a better nutrient consumption and improved the nutritional conditions of the poor and marginated urban sector of the society. ${ }^{(10)}$ It was even reported that public housing subsidy may protect the family from excessive pressure on their food budget and was associated with improved nutritional status in young children among low income families. ${ }^{(11)}$

Despite achieving a significant reduction over the past two decades, the absolute cost of food subsidies in Egypt is still high relative to the benefits received by the poor. The program is not designed to improve the nutritional status of the vulnerable groups. The subsidy scheme is under great pressure from international organizations to be eliminated. The whole debate of food subsidy in Egypt centers on economic and social consideration without 
paying any attention to its nutritional impact. ${ }^{(12)}$

In view of the limited studies on food subsidy in Egypt, this study was initiated to evaluate the current food subsidy program, assess the consumption of subsidized and unsubsidized bread, identify the various socioeconomic factors affecting the intake of subsidized foods and to determine consumers' opinion towards the subsidy program.

\section{Subjects and methods}

The subjects of this study were sampled from the administrative staff and workers at Alexandria university hospitals. The criteria for selection were that the subject should be married, having a family and holding a ration card.The minimum sample size calculated using Epi-Info version 6.0 and an alpha error of 0.05 , a null hypothesis of $75 \%$ consuming subsidized foods with 6\% precision was 201.

Each subject was privately interviewed to explain the objectives of the study and to gain his approval to participate in the study. Response was highly positive and many of them were very keen to express their opinion regarding food price subsidy.

Data were collected by direct interview using a pre-designed questionnaire which was previously tested and corrected after carrying out a pilot study .The collected data included information on the level of education and the subjects were classified into three levels, university level, middle level of education including graduates from secondary schools and technical schools and low level of education including illiterate subjects and those with primary school education. Families were classified according to family size which included all the house hold members into small families with less than five members, medium size families between five and six members and large families including seven or more members. The total family income was calculated and was divided by the family size to estimate the monthly percapita 
income. The subjects were classified into low income group with monthly percapita income less than 200LE, middle income between 200 and 400 LE and high income bracket with income exceeding 400 LE.

Each subject was requested to provide information on the total numbers of loafs of subsidized balady bread, unsubsidized shami bread and fino bread purchased daily .If bread was purchased on weekly basis or otherwise, the daily share was calculated. The number of loafs purchased from each type of bread was divided by the family size to determine the daily percapita share from each type. The fate of the purchased bread whether completely consumed, frozen or wasted was recorded. Consumers' opinion on the best approach to improve the quality of subsidized bread was recorded.

Holders of the rationing cards were questioned if they dispense the whole quantity of the allocated foods, only part of it or if they do not take the foods dispensed through the ration card including sugar, oil, rice and tea. Those who do not dispense the whole quantity or take only a part of it were questioned about the reasons for doing so. The subjects were questioned about their opinion if the food subsidy program improved the nutrition of their family members, the preferred mode of subsidy whether through ration card or direct cash subsidy and the reasons for preferring subsidy through ration cards.

Data were verified and analyzed using the SPSS version 12.0 software package. Descriptive statistics were used to present subjects characteristics. The Chi square test was used to compare association between variables, $t$ test was used to compare the difference between means, $\mathrm{P}$ values of 0.05 or less were considered statistically significant.

\section{Results}

The results show that the mean percapita share of bread was 2.63 loafs of subsidized balady bread, 0.94 loaf off 
unsubsidized shami bread and 0.91 loaf of fino bread (Table 1). The data show that percapita income, family size and educational level have a significant impact on the mean daily share of different types of bread. The binary comparison of means according to some socio-demographic criteria is presented in table 2 . The mean percapita purchase of subsidized balady bread was 3.42 loafs by low income group when compared with 1.53 loafs for high income group. The largest mean was observed among members from large families (3.71 loafs) and from low educational level (3.37 loafs), the corresponding mean for those with university education was lower to 1.13 loafs and 1.53 loafs among families with monthly percapita income exceeding 400LE.

The mean daily share of unsubsidized shami bread was significantly lower by almost all the groups investigated. However, the mean share of shami bread was higher than subsidized bread among high income families, $\bar{X}=1.71$ and 1.53 loafs respectively. ( $t=2.046, P<0.05)$. The same trend was noted among university educated level where the mean share of shami bread was 2.23 loafs which was significantly higher $(\mathrm{t}=8.87, \mathrm{p}<0.001)$ than the mean share of subsidized balady bread which was lower to 1.13 loafs daily.

The mean daily share of fino bread was higher among high income families (1.54 loafs) followed by university educated group (1.49 loafs) and was slightly lower among members of small size families (1.44 loafs). On the contrary, fino bread was least consumed by members of large size families and those with lower level of education, $\bar{X}=0.48$ and 0.58 loafs daily respectively

The results show that $75 \%$ of the subsidized balady bread was completely consumed, $14.2 \%$ was wasted and $10.8 \%$ was frozen. The fate of purchase subsidized bread varied significantly with 
the percapita income and educational level but not with the family size (Table 3 ). Low income families consumed $83.1 \%$ of the purchased bread and only $10.4 \%$ was wasted. On the other hand, high income families consumed only $59.6 \%$ of the quantity purchased , wasted $19.2 \%$ and $21.2 \%$ of the loafs were frozen. The difference was statistically significant $\left(X^{2}=\right.$ 11.13, $p<0.05)$.

The results show large size families consumed $76.9 \%$ of the purchased bread as compared with $69.6 \%$ of small size families. A comparable proportion (around $16 \%$ ) of the purchased bread was frozen by both groups; the differences were not statistically significant.

The fate of the purchased subsidized bread was significantly modified by the level of education, $\left(X^{2}=14.38, P<0.01\right)$. Low income families consumed a large proportion of the purchased bread (78.2\%) but they also wasted a significant proportion ( $17.2 \%$ ). Families with higher level of education consumed a lower proportion (64.6\%), wasted a smaller proportion (10.4\%) but stored $25.0 \%$ of the purchased bread by freezing. Such proportion is higher than that reported by any other group.

Consumers' recommendations to improve the quality of purchased bread are presented in table 4 . The data show that $23.5 \%$ of the subjects recommended an increase in the price of bread, $28.9 \%$ recommended improved baking while $46.7 \%$ did not want any change. The results show that $44.2 \%$ of the high income group recommended an increase in the price of subsidized bread as compared with $11.7 \%$ of the low income families who either recommended improved baking $(27.3 \%)$ or simply recommended no change. The difference was statistically significant, $\quad X^{2}=21.31, P<0.001$.

The type of recommendations also varied with family size as $25.3 \%$ of small size families recommended a price 
increase as compared with $12.8 \%$ of large size families. The majority of the latter group (64.1\%) did not want any change in the present system. The difference was statistically significant, $\mathrm{X}^{2}=9.34, \mathrm{P}<0.05$. The level of education had a strong impact on the nature of recommendations to improve the quality of subsidized bread, $\mathrm{X}^{2}$ $=46.31, \mathrm{P}<0.001$. The majority of the university educated group (43.7\%) recommended an increase in price, improved baking was mostly recommended by families with middle level of education (40.6\%). The majority of the group with low educational recommended no change (72.4\%).

The impact of income on dispensing foods allocated through ration card monthly is presented in table 5 . Sugar ration was taken by $78 \%$ of the families without significant variation between various income groups ( $\mathrm{X} 2=3.78, \mathrm{NS})$. However, it was noted that $13.5 \%$ of the high income families did not take the sugar ration.
Oil ration was dispensed by $79.2 \%$ of the low income families and was only taken by $61.5 \%$ of the high income bracket. The data show that only $17.3 \%$ of the former group did not dispense the allocated oil ration.

Uptake of rice ration was significantly modified by income $\left(\mathrm{X}^{2}=21.32, \mathrm{P}<\right.$ $0.001)$. On the average, $57.8 \%$ of the surveyed families dispensed the whole rice ration; such proportion was as low as $32.7 \%$ of high income group and increased to $67.5 \%$ among low income families. The results show that $19.1 \%$ of the families did not take any rice and $23.0 \%$ collected only a portion of the allocated quantity.

Rationed tea uptake was significantly modified by income $\left(\mathrm{X}^{2}=35.48\right.$. $\left.\mathrm{P}<0.001\right)$ and was dispensed by $49.5 \%$ of the families. The data show that only $15.4 \%$ of the high income group dispensed the rationed tea, such proportion increased to $66.2 \%$ among low income families. A large 
proportion of the high income bracket did not dispense the allocated rationed tea.

The reasons given by ration card holders for not dispensing allocated subsidized foods varied significantly with the type of food $\left(X^{2}=27.30, P<0.00\right)$. Tea and rice were rejected because of their poor quality, $61.2 \%$ and $44.2 \%$ respectively. Only $26.7 \%$ of the subjected reported that sugar was of poor quality. Rice was not taken by $29.15 \%$ of the families because they could not afford its price. A large proportion of the subjects did not dispense the whole allocated quantity of sugar and rice because the ration quantity exceeded their needs (table 6).

The effect of educational level on consumers' opinion regarding food subsidy program through rationing card is presented in table 7 .The results show that $48.0 \%$ believed that the program improved their nutritional status; such ratio was as high as $58.6 \%$ among the group with limited education and was lower to $29.2 \%$ among university graduates. On the other hand, $28.9 \%$ reported that it has no effect, such opinion was mostly expressed by the university educated group, the difference was statistically significant, $\mathrm{X} 2=12.57$, $\mathrm{P}<0.01$.

The results show that $52 \%$ of the subjects preferred ration cards over cash subsidy (48.0\%). The latter mode of subsidy was preferred by $64.5 \%$ of the university graduates while ration card was mostly preferred by the group with low education (66.7\%); the difference was statistically significant, $X^{2}=14.17$, $P<0.001)$

The main reasons for preferring ration card over cash subsidy were the belief that cash subsidy will not be enough (54.7\%), the expected increase in the prices of foods $(25.5 \%)$ and the possible food shortage (19.8\%). The most common reason given by subjects with limited education was the belief that cash will not be enough $(67.2 \%)$, such proportion was 
significantly lower $\left(X^{2}=10.66, P<0.05\right)$

to only $29.4 \%$ among university educated

subjects who believed that cash subsidy

will lead to foods shortage

\section{Discussion}

Bread, the staple food, enjoys a very special place in the Egyptian diet. It is made from heavily subsidized wheat flour or wheat mixed with maize flour. Egyptians eat food with bread and not bread with food. ${ }^{(13)}$

Balady bread and flour subsidies were not designed to serve the poor alone, since these foods are available to any consumer, while there is a very widespread perception that self-targeting has resulted in balady bread and flour being relatively more consumed by the poor, a high percentage of bread and flour subsidies go to the non poor.(14)

It is assumed that only the lowest quality bread is subsidized and that rich community will buy better quality products. However, as subsidized bread is cheaper than animal fed, many poultry and cattle growers abuse the effort of the government to provide subsidized bread for the low income groups.

The results of this study show that subsidized balady is consumed by all socio-economic strata, however, the rate of consumption showed significant variation (table 1). The mean daily share of balady bread was more than 3 loafs daily for low income group, large size families and those with limited education. Low income families can not afford the price of shami of fino bread which is $4-5$ times, higher than the subsidized bread.

When the head of the family faces the problem of inflation and low income, he has no alternative other than purchasing a large number of loafs of subsidized bread that is less expensive than any other source of calories. Better educated small families with higher income, consume more of the shami and fino bread and reduce their consumption of balady bread which 
requires a strong effort to purchase from over-crowded bakeries. It is postulated that fino bread is used by all families to prepare sandwiches for their school children.

The fate of the purchased subsidized bread was also affected by the socioeconomic characteristics of the family. Low income families who suffer from the burden of inflation consume $83.1 \%$ of the purchased bread, high income bracket consumed less (59.6\%) but they refrigerated a higher percentage of the bread $(21.2 \%)$. High income families with better education consumed a relatively lower proportion of the subsidized bread but because of the difficulty in obtaining this bread, they were more keen to keep the excess by refrigeration. In the mean time, it was noted that $14.2 \%$ of the purchased bread was wasted, such proportion was as high $19.2 \%$ among high income families. This is mostly due to the poor quality of the bread which becomes inedible if kept without refrigeration for few hours.

The percentage of wasted bread was much lower than that reported in 1992 which amounted to $20.8 \%$. $^{(15)}$ Although the drop in bread waste occurred over 18 years, extensive education program should be implemented and directed to housewives to reduce bread waste to a minimum level.

Consumer's recommendations to improve the quality of subsidized bread varied considerably. Around $46.7 \%$ of the subjects did not want any change in the current system. They accept the poor quality of the low price bread fearing that any improvement will be accompanied by an increase of its price which they can not afford. This was mostly mentioned by large size, low income families with limited education (table 4). Around $28.9 \%$ of the subjects recommended improved baking without any charge in the price of the bread assuming that the government should be 
responsible for that. Improved baking will contribute significantly to reduce bread wasted. A small proportion of the subjects who were mostly with university education and better income recommended an increase in the price of bread. They postulated that such hike in the price should be used to improve the quality and the taste of bread, reduce the waste and the use of subsidized bread in feeding animals.

In contrast to bread and flour subsidies, sugar, oil, rice and tea subsidies are explicitly designed to be targeted. These food are dispensed through the ration card. The quantities actually dispensed from each food varied considerably. The whole allocated quantity of sugar was dispensed by $78 \%$ of the subjects compared with $49.5 \%$ of the allocated tea (table 5). It was of interest to note that $22.3 \%$ of the subject did not dispense the rationed subsidized sugar either partially or completely (table 5). The main reason for doing so was that the allocated quantity exceeded their needs (48.9\%), poor quality (26.7\%) and almost one quarter of the sample could not afford to purchase the whole quantity of subsidized sugar (table 6).

The quantity of ration cooking oil exceeds the needs of some families and was dispensed completely by $71.6 \%$ of the subjects. However, $29.3 \%$ of the subjects reported that the quality of oil is poor. This is true, rationed oil is usually turbid and its odor is some times not acceptable. ${ }^{(16)}$ Uncollected oil is usually sold on the black market to small restaurants that do not pay much attention to quality.

Rice is a very popular food, it comes second to bread as the source of calories. More than $28.0 \%$ of the subjects did not collect the whole allocated quantity. It was reported that card rice is of poor quality (44.2\%). There is a large difference in the quality between subsidized rice and that available on the market. The difference in 
the price is not too large which encourages the family to purchase better quality rice from the free market (table 6).

Tea was the most unaccepted rationed item and was dispensed by only $49.5 \%$ of the families. The main reason given was its poor quality (table 6). Tea may be considered the national drink and is consumed several times daily. It replaces fruits as it is the habit to have a glass of sweet tea shortly after meals. Unless the quality and taste are good, tea will not be accepted by the consumer.

The nutritional value of subsidized foods is very poor, rice, oil, sugar are calorie rich foods and bread could cover a good portion of the daily caloric requirement, however, they are very poor in vitamins and minerals, the protein contents of rice and bread are relatively low and are of poor biological value. The results show that $48 \%$ of the sample believed that subsidy program improved their nutrition. The university educated subjects who have a limited knowledge about nutrition believed that it has partial or no effect on the nutrition of their family members (table 7). The composition of the subsidized foods dispensed through the current program can not contribute to improving the nutritional status of the vulnerable groups of the society.

Available data show that the card system is poorly targeted. More than $25 \%$ of the poor families do not carry a ration card because of the bureaucratic steps necessary to acquire a ration card. ${ }^{(17)}$ Another major problem of the food subsidy program is the volume of leakage of those subsidies to the high income bracket.(18) In addition, foods allocated through the ration cards and not collected by the consumer, are usually sold on the black market, This way, the economic benefits of subsidy never reaches the group targeted by the program.

Despite of its drawbacks, more than 
$50 \%$ of the sample recommended a the price of foods. Food shortage was a continuation of the current system of major concern for the educated group dispensing the subsidized foods through the ration cards. This proportion was as high as (41.2\%) but not for those with limited income whose needs are quite limited.

$66.7 \%$ among the group with limited

Both government and public fear that education. High educated group preferred transformation to cash system will result in a cash subsidy (64.5\%), they believe that they high rate of inflation. There is no control how could use the cash to purchase the foods they need only and would have the chance to purchase better quality foods. Those who preferred ration card subsidy were worried that cash subsidy will not be enough (54.7\%) and will be followed by a sharp increase in cash subsidy will be spent by recipients. It is recommended to reform and develop the current food subsidy program to guarantee reaching the low income group, reduce leakage and improve the quality of subsidized foods.

Table 1: Mean daily percapita purchase of different types of bread.

\begin{tabular}{|l|c|c|c|c|c|}
\hline \multirow{4}{*}{\multicolumn{1}{|c|}{ Variable }} & \multicolumn{3}{|c|}{ Mean daily purchase of bread } & \multicolumn{2}{c|}{} \\
\cline { 2 - 5 } & $\begin{array}{c}\text { Subsidized } \\
\text { Balady (A) }\end{array}$ & $\begin{array}{c}\text { Unsubsidized } \\
\text { Shami (B) }\end{array}$ & $\begin{array}{c}\text { Fino } \\
\text { Bread (C) }\end{array}$ & \multicolumn{2}{c|}{ Total } \\
\cline { 2 - 6 } & $\bar{X} \pm \mathbf{s d}$ & $\bar{X} \pm \mathbf{s d}$ & $\bar{X} \pm \mathbf{s d}$ & No. & $\%$ \\
\hline $\begin{array}{l}\text { Monthly percapita } \\
\text { income (L.E) }\end{array}$ & & & & & \\
\hline$<200$ & $3.42 \pm 1.71$ & $0.59 \pm 0.76$ & $0.61 \pm 0.42$ & 77 & 37.7 \\
\hline $200-$ & $2.54 \pm 1.53$ & $0.75 \pm 0.79$ & $0.82 \pm 0.41$ & 75 & 36.8 \\
\hline $400+$ & $1.53 \pm 0.82$ & $1.73 \pm 1.13$ & $1.54 \pm 0.75$ & 52 & 25.5 \\
\hline Family Size & & & & & \\
\hline$<5$ & $1.64 \pm 0.98$ & $1.58 \pm 0.41$ & $1.44 \pm 0.96$ & 79 & 38.7 \\
\hline $5-$ & $2.97 \pm 1.26$ & $0.61 \pm 0.67$ & $0.63 \pm 0.58$ & 86 & 42.2 \\
\hline $7+$ & $3.71 \pm 1.69$ & $0.37 \pm 0.22$ & $0.48 \pm 0.96$ & 39 & 19.1 \\
\hline Educational level & & & & & \\
\hline University & $1.13 \pm 0.91$ & $2.23 \pm 1.52$ & $1.49 \pm 0.88$ & 48 & 23.5 \\
\hline Middle & $2.69 \pm 1.42$ & $0.72 \pm 0.63$ & $0.93 \pm 0.61$ & 69 & 33.8 \\
\hline Low & $3.37 \pm 1.79$ & $0.41 \pm 0.72$ & $0.58 \pm 0.34$ & 87 & 42.7 \\
\hline Total & $\mathbf{2 . 6 3 \pm 0 . 8 6}$ & $\mathbf{0 . 9 4 \pm 0 . 4 7}$ & $\mathbf{0 . 9 1 \pm 0 . 3 8}$ & $\mathbf{2 0 4}$ & $\mathbf{1 0 0}$ \\
\hline
\end{tabular}


Table 2: Binary comparison of mean purchase of different types of bread according to some sociodemographic criteria listed in table 1.

\begin{tabular}{|l|c|c|c|c|c|c|}
\hline \multirow{3}{*}{ Variable } & \multicolumn{6}{|c|}{ Comparisons } \\
\cline { 2 - 7 } & \multicolumn{2}{|c|}{$\mathbf{A} \times \mathbf{B}$} & \multicolumn{2}{c|}{$\mathbf{A} \times \mathbf{C}$} & \multicolumn{2}{c|}{$\mathbf{B \times C}$} \\
\cline { 2 - 7 } $\begin{array}{l}\text { Monthly percapita } \\
\text { Income (L.E) }\end{array}$ & & & $\mathbf{P}=$ & $\mathbf{P}=$ & $\mathbf{t}$ & $\mathbf{P}=$ \\
\hline$<200$ & 21.60 & 0.00 & 22.79 & 0.00 & 0.329 & 0.74 \\
\hline $200-$ & 14.85 & 0.00 & 15.51 & 0.00 & 1.123 & 0.26 \\
\hline $400+$ & 2.046 & 0.04 & 0.129 & 0.89 & 2.001 & 0.05 \\
\hline Family Size & & & & & & \\
\hline$<5$ & 0.807 & 0.42 & 2.082 & 0.03 & 1.916 & 0.06 \\
\hline $5-$ & 23.62 & 0.00 & 24.095 & 0.00 & 0.322 & 0.74 \\
\hline $7+$ & 27.99 & 0.00 & 23.74 & 0.00 & 1.600 & 0.11 \\
\hline Educational level & & & & & & \\
\hline University & 8.87 & 0.00 & 4.06 & 0.00 & 6.018 & 0.00 \\
\hline Middle & 18.11 & 0.00 & 16.27 & 0.00 & 3.42 & 0.00 \\
\hline Low & 21.91 & 0.00 & 21.87 & 0.00 & 3.05 & 0.00 \\
\hline
\end{tabular}

Table 3: Fate of purchased subsidized Balady Bread.

\begin{tabular}{|c|c|c|c|c|c|c|c|c|}
\hline \multirow{3}{*}{ Variable } & \multicolumn{6}{|c|}{ Fate of Bread } & \multirow{2}{*}{\multicolumn{2}{|c|}{ Total }} \\
\hline & \multicolumn{2}{|c|}{$\begin{array}{l}\text { Completely } \\
\text { consumed }\end{array}$} & \multicolumn{2}{|c|}{ Refrigerated } & \multicolumn{2}{|c|}{ Wasted } & & \\
\hline & No. & $\%$ & No. & $\%$ & No. & $\%$ & No. & $\%$ \\
\hline \multicolumn{9}{|l|}{$\begin{array}{l}\text { Monthly percapita } \\
\text { Income (L.E) }\end{array}$} \\
\hline$<200$ & 64 & 83.1 & 5 & 6.5 & 8 & 10.4 & 77 & 37.7 \\
\hline $200-$ & 58 & 77.3 & 6 & 8.0 & 11 & 14.7 & 75 & 36.8 \\
\hline \multirow[t]{2}{*}{$400+$} & 31 & 59.6 & 11 & 21.2 & 10 & 19.2 & 52 & 25.5 \\
\hline & \multicolumn{8}{|c|}{$X^{2}=11.13, p<0.05$} \\
\hline \multicolumn{9}{|l|}{ Family Size } \\
\hline$<5$ & 59 & 69.6 & 11 & 13.9 & 13 & 16.5 & 79 & 38.7 \\
\hline $5-$ & 68 & 79.1 & 8 & 9.3 & 10 & 11.6 & 86 & 42.2 \\
\hline $7+$ & 30 & 76.9 & 3 & 7.7 & 6 & 15.4 & 39 & 19.1 \\
\hline & \multicolumn{8}{|c|}{$X^{2}=1.94$, NS } \\
\hline \multicolumn{9}{|l|}{ Educational level } \\
\hline University & 31 & 64.6 & 12 & 25.0 & 5 & 10.4 & 48 & 23.5 \\
\hline Middle & 54 & 78.3 & 6 & 8.7 & 9 & 13.0 & 69 & 33.8 \\
\hline Low & 68 & 78.2 & 4 & 4.6 & 15 & 17.2 & 87 & 42.7 \\
\hline \multirow[t]{2}{*}{ Total } & 153 & 75.0 & 22 & 10.8 & 29 & 14.2 & 204 & 100 \\
\hline & \multicolumn{8}{|c|}{$X^{2}=14.38, p<0.01$} \\
\hline
\end{tabular}


Table 4: Consumers' recommendations to improve the quality of subsided bread.

\begin{tabular}{|c|c|c|c|c|c|c|c|c|}
\hline \multirow{3}{*}{ Variable } & \multicolumn{6}{|c|}{ Consumers' recommendations } & \multirow{2}{*}{\multicolumn{2}{|c|}{ Total }} \\
\hline & \multicolumn{2}{|c|}{$\begin{array}{c}\text { Increase } \\
\text { price }\end{array}$} & \multicolumn{2}{|c|}{$\begin{array}{c}\text { Improve } \\
\text { baking }\end{array}$} & \multicolumn{2}{|c|}{$\begin{array}{c}\text { No. } \\
\text { Change } \\
\end{array}$} & & \\
\hline & No. & $\%$ & No. & $\%$ & No. & $\%$ & No. & $\%$ \\
\hline \multicolumn{9}{|l|}{$\begin{array}{l}\text { Monthly percapita } \\
\text { income (L.E) }\end{array}$} \\
\hline$<200$ & 9 & 11.7 & 21 & 27.3 & 47 & 61.0 & 77 & 37.7 \\
\hline $200-$ & 16 & 21.3 & 26 & 34.7 & 33 & 44.0 & 75 & 36.8 \\
\hline \multirow[t]{2}{*}{$400+$} & 23 & 44.2 & 12 & 23.1 & 17 & 23.7 & 52 & 25.5 \\
\hline & \multicolumn{8}{|c|}{$X^{2}=21.31, p<0.001$} \\
\hline \multicolumn{9}{|l|}{ Family Size } \\
\hline$<5$ & 20 & 25.3 & 19 & 24.1 & 40 & 50.6 & 79 & 38.7 \\
\hline $5+$ & 23 & 26.7 & 31 & 36.5 & 32 & 48.8 & 86 & 42.2 \\
\hline \multirow[t]{2}{*}{$7+$} & 5 & 12.8 & 9 & 23.1 & 25 & 64.1 & 39 & 19.1 \\
\hline & \multicolumn{8}{|c|}{$X^{2}=9.34, p<0.05$} \\
\hline \multicolumn{9}{|l|}{ Educational level } \\
\hline University & 21 & 43.7 & 19 & 39.6 & 8 & 16.7 & 48 & 23.5 \\
\hline Middle & 15 & 21.7 & 28 & 40.6 & 26 & 37.7 & 69 & 33.8 \\
\hline Low & 12 & 13.8 & 12 & 13.8 & 63 & 72.4 & 87 & 42.7 \\
\hline Total & 48 & 23.5 & 59 & 28.9 & 97 & 46.7 & 204 & 100 \\
\hline & & & & $=$. & & & & \\
\hline
\end{tabular}


Table 5: Impact of income on dispensing foods allocated through rationing card monthly.

\begin{tabular}{|c|c|c|c|c|c|c|c|c|}
\hline \multirow{3}{*}{$\begin{array}{l}\text { Percapita } \\
\text { income } \\
\text { (L.E) }\end{array}$} & \multicolumn{6}{|c|}{ Dispensed quantity } & \multirow{2}{*}{\multicolumn{2}{|c|}{ Total }} \\
\hline & \multicolumn{2}{|c|}{ Whole quantity } & \multicolumn{2}{|c|}{ Partially } & \multicolumn{2}{|c|}{ None } & & \\
\hline & No. & $\%$ & No. & $\%$ & No. & $\%$ & No. & $\%$ \\
\hline \multicolumn{9}{|l|}{ Sugar } \\
\hline$<200$ & 64 & 83.1 & 8 & 10.4 & 5 & 6.5 & 77 & 37.7 \\
\hline $200-$ & 59 & 78.7 & 10 & 13.3 & 6 & 8.0 & 75 & 36.8 \\
\hline $400+$ & 36 & 69.2 & 9 & 17.3 & 7 & 13.5 & 52 & 25.5 \\
\hline \multirow[t]{2}{*}{ Total } & 159 & 78.0 & 27 & 13.2 & 18 & 8.8 & 204 & 100 \\
\hline & \multicolumn{8}{|c|}{$X^{2}=3.70, N S$} \\
\hline \multicolumn{9}{|l|}{ Oil } \\
\hline$<200$ & 61 & 79.2 & 9 & 11.7 & 7 & 9.1 & 77 & 37.7 \\
\hline $200-$ & 53 & 70.7 & 14 & 18.7 & 8 & 10.6 & 75 & 36.8 \\
\hline $400+$ & 32 & 61.5 & 11 & 21.2 & 9 & 17.3 & 52 & 25.5 \\
\hline Total & 146 & 71.6 & 34 & 16.7 & 24 & 11.7 & 204 & 100 \\
\hline & \multicolumn{8}{|c|}{$X^{2}=5.265, N S$} \\
\hline \multicolumn{9}{|l|}{ Rice } \\
\hline$<200$ & 52 & 67.5 & 17 & 22.1 & 8 & 10.4 & 77 & 37.7 \\
\hline $200-$ & 49 & 65.3 & 14 & 18.7 & 12 & 16.0 & 75 & 36.8 \\
\hline$\overline{400+}$ & 17 & 32.7 & 16 & 30.8 & 19 & 36.5 & 52 & 25.5 \\
\hline \multirow[t]{2}{*}{ Total } & 118 & 57.8 & 47 & 23.0 & 39 & 19.1 & 204 & 100 \\
\hline & \multicolumn{8}{|c|}{$X^{2}=21.32, p<0.001$} \\
\hline \multicolumn{9}{|c|}{ (1) } \\
\hline$<200$ & 51 & 66.2 & 12 & 15.6 & 14 & 18.2 & 77 & 37.7 \\
\hline $200-$ & 42 & 56.0 & 14 & 18.7 & 19 & 25.3 & 75 & 36.8 \\
\hline $400+$ & 8 & 15.4 & 15 & 28.8 & 29 & 55.8 & 52 & 2.5 \\
\hline \multirow[t]{2}{*}{ Total } & 101 & 49.5 & 41 & 20.1 & 62 & 30.4 & 204 & 100 \\
\hline & \multicolumn{8}{|c|}{$X^{2}=35.48, p<0.001$} \\
\hline
\end{tabular}

Table 6: Reasons given by rationing card holders for not dispensing allocated subsidized foods.

\begin{tabular}{|l|c|c|c|c|c|c|c|c||}
\hline \multirow{3}{*}{ Type of food } & \multicolumn{9}{|c|}{ Reasons given } & \multicolumn{2}{|c|}{ Total } \\
\cline { 2 - 10 } & \multicolumn{2}{|c|}{$\begin{array}{c}\text { Poor } \\
\text { quality }\end{array}$} & \multicolumn{2}{c|}{ Can not afford } & \multicolumn{2}{c|}{$\begin{array}{c}\text { Large } \\
\text { quantity }\end{array}$} & \multicolumn{2}{|c|}{} \\
\cline { 2 - 10 } & No. & $\%$ & No. & $\%$ & No. & $\%$ & No. & $\%$ \\
\hline Sugar & 12 & 26.7 & 11 & 24.4 & 22 & 48.9 & 45 & 100 \\
\hline Oil & 17 & 29.3 & 14 & 24.1 & 27 & 46.6 & 58 & 100 \\
\hline Rice & 38 & 44.2 & 25 & 29.1 & 23 & 26.7 & 86 & 100 \\
\hline Tea & 63 & 61.2 & 16 & 15.5 & 24 & 23.3 & 103 & 100 \\
\hline
\end{tabular}


Table 7: Effect of educational level on consumers' opinion regarding food subsidy program through rationing card.

\begin{tabular}{|c|c|c|c|c|c|c|c|c|}
\hline \multirow[b]{3}{*}{ Variable } & \multicolumn{6}{|c|}{ Educational level } & \multirow{2}{*}{\multicolumn{2}{|c|}{ Total }} \\
\hline & \multicolumn{2}{|c|}{ University } & \multicolumn{2}{|c|}{ Middle } & \multicolumn{2}{|c|}{ Low } & & \\
\hline & No. & $\%$ & No. & $\%$ & No. & $\%$ & No. & $\%$ \\
\hline \multicolumn{9}{|l|}{ Effect on nutrition } \\
\hline Improved & 14 & 29.2 & 33 & 47.8 & 51 & 58.6 & 98 & 48.0 \\
\hline Partially & 15 & 31.3 & 13 & 18.9 & 19 & 21.8 & 47 & 23.1 \\
\hline No effect & 19 & 39.5 & 23 & 33.3 & 17 & 21.8 & 59 & 28.9 \\
\hline \multirow[t]{2}{*}{ Total } & 48 & 100 & 69 & 100 & 87 & 100 & 204 & 100 \\
\hline & \multicolumn{8}{|c|}{$X^{2}=12.573, p<0.01$} \\
\hline \multicolumn{9}{|l|}{$\begin{array}{l}\text { Preferred mode of } \\
\text { subsidy }\end{array}$} \\
\hline Cards & 17 & 35.5 & 31 & 44.9 & 58 & 66.7 & 106 & 52.0 \\
\hline Cash & 31 & 64.5 & 38 & 55.1 & 29 & 33.3 & 98 & 48.0 \\
\hline \multirow[t]{2}{*}{ Total } & 48 & 100 & 69 & 100 & 87 & 100 & 204 & 100 \\
\hline & \multicolumn{8}{|c|}{$X^{2}=14.168, p<0.001$} \\
\hline \multicolumn{9}{|l|}{$\begin{array}{l}\text { Reasons for preferring } \\
\text { ration Card }\end{array}$} \\
\hline Cash will not be enough & 5 & 29.4 & 14 & 45.2 & 39 & 67.2 & 58 & 54.7 \\
\hline $\begin{array}{l}\text { Increase in price of } \\
\text { foods }\end{array}$ & 5 & 29.4 & 9 & 29.0 & 13 & 22.4 & 27 & 25.5 \\
\hline Food shortage & 7 & 41.2 & 8 & 25.8 & 6 & 10.3 & 21 & 19.8 \\
\hline \multirow[t]{2}{*}{ Total } & 17 & 100 & 31 & 100 & 58 & 100 & 106 & 100 \\
\hline & \multicolumn{8}{|c|}{$X^{2}=10.658, p<0.05$} \\
\hline
\end{tabular}

\section{REFERENCES}

1. Akhter Au, Bouis HE. weighing what's practical: Proxy means tests for targeting food subsidy in Egypt. Food policy. 2002; 5-6: 519-540.

2. Ali, S M, Adams R H, Jr. The Egyptian Food Subsidy System: Operation and Effects on Income Distribution. World Development. 1996; 24 (11): 17771791

3. Alderman $\mathrm{H}$, von Braun J, Sakr S S Egypt's Food Subsidy and Rationing System: A Description. Research Report 34. Washington, D.C.: International Food Policy Research Institute. 1982.

4. Badiane, $\mathrm{O}$, Kherallah $\mathrm{M}$, Abdel-Latif
A.. Evaluation of Wheat Policy Reform in Egypt and Adjustment of Local Markets. A deliverable of the Food Security Research Project in Egypt. International Food Policy Research Institute, Washington, D.C. 1998.

5. Gutner T. The Political economy of food subsidy reform in Egypt. Washington, D.C: International Food Policy Research Institute. IFPRI; 1999.

6. Abdel-Latif, A, El-Laithy $\mathrm{H}$. Protecting Food Security for the Poor in a Liberalizing Economy. In Egypt's Agriculture in a Reform Era, ed. L.B. 
Fletcher. Ames, lowa, U.S.A: lowa State University Press. 1996

7. Kochar, A. "Can Targeted Food Programs Improve Nutrition? An Empirical Analysis of Indi's Public Distribution System, "Economic Development and Cultural Change 2005; 54 (1), 203-35.

8. Tarozzi, A. "The Indian Public Distribution System as a Provider of Food Security: Evidence from Child Nutrition in Andhra Pradesh, "European Economic Review. 2005; 49: 1305-1330.

9. Herman Dr. Harrison GG, Afifi AA, Jenks $E$. Effect of targeted subsidy on intake of fruits and vegetables in the special supplementation nutrition program for women, infants and children. Am J. public Health. 2008; 98(1) : 98-105.

10. Shamah LV, Avila CA, Cuevasnl, Chivez VA, A vila MA, Mendoza C. The tortilla subsidy in Mexico: a nutritional or economic program. Arch Latinoam Nutri 2003; 53 (1): 5-13.

11. Meyer A, Cutts D, Frank DA, Levenson S, Skalicky A, Heeren T, Cook J, Berkowitz C, Black M, Casey $\mathrm{P}$, Zaldivar M. Subsidized housing and children's nutritional status: data from a multisite surveillance study. Arch pediatr Adolesc Med. 2005; 159 (6): 551-6.
12. Harik, I Subidization in Egypt: Neither economic growth nor districution. International Journal of Middle East Studies. 1992; 24: 481-499.

13. Wassef $H$. Food habits of the Egyptians: Newly emerging trends. Eastern Mediterranean Health Journal. 2004; 10 (6): 848-915.

14. Ahmed, A U, Bouis $H$ E, Ali SM. Performance of the Egyptian Food Subsidy System: Distribution, Use, Leakage, Targeting, and CostEffectiveness. International Food Policy Research Institute, Washington, D.C. 1998.

15. Amine Ek, Amin AK, Eldin Ms, Zaghloul N. The impact of partial termination of food subsidy programme on food consumption pattern. J. Egypt. Pub. Hlth. Assoc. 1990; 66: 193-205.

16. Ali SM, Adams RH. The Egyptian food subsidy systems. Operation and effects on income distribution. World development. 1996; 24 (11): 1777-91.

17. Salmi. Alleviating poverty during structural adjustment. World Bank. Washington. D.C. 1991.

18. Salevurakis J, Abdel-Haleim S. Bread subsidies in Egypt: Choosing social stability or fiscal responsibility. Review of Radical Political Economics. 2008; 40 (1): 35-49. 